UDC 33.021-028.6

DOI: $10.15673 /$ fie.v10i2.967

\author{
Stupnytska T. \\ Ph.D., Associate Professor \\ Department of Accounting and Auditing \\ E-mail: t.stupnitska@gmail.com
}

Pryimak V.

The student of the fourth grade of Economy, Business and Control Faculty

Odessa National Academy of Food Technologies

Kanatna str., 112, Odessa, Ukraine, 65039

E-mail: priymak_vika@hotmail.com
Yevtushevska 0.

Department of Accounting and Auditing

E-mail: olga163alex@gmail.com
$\mathrm{PhD}$, Associate Professor

\title{
THE ANALYSIS OF APPROACHES TO THE ESSENCE AND CLASSIFICATION OF FIXED ASSETS
}

\begin{abstract}
Effectiveness of use of fixed assets depends on the organization of timely receipt of reliable and sufficiently complete accounting and economic information. In this regard, the role and significance of accounting as one of the most important management functions increases. One of the essential elements for improving the organization of accounting and analysis of fixed assets is their definition and classification. The article studies essence of the category "fixed assets" and approaches to their classification in order to improve their management, conduct qualitative management analysis and accounting. The conducted study made it possible to systematize approaches to the classification of the category "fixed assets" in accordance with regulatory and legal acts regulating their accounting and taxation in all economic entities, namely the Regulations of Accounting (Standard) 7 "Fixed Assets", International Accounting Standard 16 "Fixed Assets" and the Tax Code of Ukraine. The classification of fixed assets is presented on the forms of statistical and financial statements, and the analysis of approaches to their classification in the work of scientists according to their functional purpose, by affiliation, by industries and feature of use is carried out.
\end{abstract}

Key words: fixed assets, classification of fixed assets, group of fixed assets, classes of fixed assets, normative-legal acts.

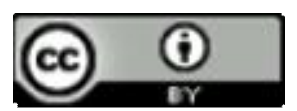

This work is licensed under a Creative Commons Attribution 4.0 International License http://creativecommons.org/licenses/by/4.0/
Statement of the problem and its connection with important scientific and practical tasks. The main task of Ukrainian enterprises is to increase the efficiency of using the material and technical base of the enterprise in the conditions of acute shortage of investment resources. Therefore, enterprises need to invest their capital in long-term tangible assets. Effective use of them enables to increase production and influence on the final financial result of an enterprise. To do this, management of enterprise needs to implement control over the effective use of fixed assets. The necessary element of the organization of accounting and control of fixed assets is their economic definition and classification. One of the factors of the analysis is classification of fixed assets by various features. And choice of the correct criterion for classification affects the quality of the analysis.

The analysis of the latest publications on the problem. The questions of the concept and classification of fixed assets of an enterprise were considered in the scientific works of such scientists as: Pyrizhok Ye.S. [12] Babich V. [5], Yalovega L.V. [12], Grechko S. M. [6], Suk L.K. and Suk L.L. [11] Agres O.G. [4], Kovalenko O.V. [7], Nemish Yu.V. [9], Kovaliov D. [8], Tkachenko N.M. [8], et al. However, today there is no single ap- proach to interpretation of the category of "fixed assets" and their classification.

Forming of the aims of the research. The purpose of the article is to analyze definition of the concept, economic content and classification of the category "fixed assets" according to regulatory and normativelegal acts, which is used in the field of Ukrainian legal field and in economic literature. Choice of the criterion for the classification of fixed assets leads to improved accounting practices in enterprises and influences the implementation of qualitative analysis.

Giving an account of the main results and their substantiation. Fixed assets are used by all economic entities to carry out their activities.

The concept of "fixed assets" is interpreted differently in contemporary research by domestic scientists. There are some differences in the normative-legal acts regarding the interpretation of this concept. Therefore, it is expedient to consider this issue in two directions: in accordance with the requirements of regulatory framework and scientific approach.

In Ukraine, the issue of accounting for fixed assets is regulated by such basic normative acts as the Tax Code of Ukraine [1] and the Regulation (Standard) of 
Accounting 7 "Fixed Assets" [2]. Today, most business entities are moving to the international accounting standards, so it is worth analyzing the essence of fixed assets in accordance with International Accounting Standard 16 "Fixed Assets" (Table 1).

The essence of the concept of "fixed assets" by normative -legal acts*

\begin{tabular}{|l|l|}
\hline \multicolumn{1}{|c|}{$\begin{array}{c}\text { Normative } \\
\text { document }\end{array}$} & \multicolumn{1}{c|}{ Definition of fixed assets } \\
\hline $\begin{array}{l}\text { Tax Code } \\
\text { of Ukraine [1] }\end{array}$ & $\begin{array}{l}\text { tangible assets, including mineral deposits for use in the subsurface areas designated by the } \\
\text { taxpayer for use in the economic activity of the taxpayer the value of which exceeds 6000 } \\
\text { UAH and is gradually reduced due to physical or moral depreciation and the expected useful } \\
\text { life (exploitation) of which is more than one year from the date of commissioning. }\end{array}$ \\
\hline $\begin{array}{l}\text { R(S)AC 7 «Fixed } \\
\text { assets» [2] }\end{array}$ & $\begin{array}{l}\text { long-term tangible assets that the enterprise uses for their use in the process of producing } \\
\text { goods, rendering services, leasing to other persons, expected useful life (exploitation) of } \\
\text { which is more than one year. }\end{array}$ \\
\hline $\begin{array}{l}\text { ISAC 16 «Fixed } \\
\text { assets» [3] }\end{array}$ & $\begin{array}{l}\text { material objects used in the production or supply of goods or services, for leasing to other } \\
\text { people or for administrative purposes, and are expected to be used in more than one reporting } \\
\text { period. }\end{array}$ \\
\hline
\end{tabular}

* Compiled by the authors on the basis of source analysis

After analyzing normative - legal acts, one can conclude that under "fixed assets" long-term tangible assets that should be used for more than one year. Only in Tax Code of Ukraine are meant a value criterion, is allo- cated according to which the non-current asset is included in the fixed assets.

In the economic literature there is also no single approach to the concept of the category "fixed assets" (Table 2).

Table 2

Definition of the category "fixed assets" in the economic literature*

\begin{tabular}{|c|c|}
\hline Author, source & Definition of fixed assets \\
\hline Agres O.G. $[4$, p. 178$]$ & $\begin{array}{l}\text { means of labor in the form of tangible assets that enterprise holds for use in the production } \\
\text { process or the implementation of administrative or socio-cultural functions, the expected use- } \\
\text { ful life of which is more than one year, without changing their forms and sizes, the cost of } \\
\text { which is not less from the legal size and is gradually transferred to the extent of physical agi- } \\
\text { tation and (or) moral aging on the value of finished goods by deducting depreciation }\end{array}$ \\
\hline $\begin{array}{l}\text { Babich V. } \\
{[5, \text { p. } 11]}\end{array}$ & $\begin{array}{l}\text { a set of means of labor, which function in the field of material production in the unchanged } \\
\text { natural form for a long time and transfer their value to the newly created product in parts as } \\
\text { they wear out. }\end{array}$ \\
\hline $\begin{array}{l}\text { Butynets F. F., } \\
\text { Lyshylenko O.V. } \\
{[6, \text { p.126; 12] }}\end{array}$ & $\begin{array}{l}\text { Fixed assets - tangible assets held by an enterprise for the purpose of their use in the process } \\
\text { of production or supply of goods, provision of services, leasing to other persons or for carry- } \\
\text { ing out administrative and socio-cultural functions, the expected useful life (exploitation) of } \\
\text { which is more than one year ( or operating cycle if it exceeds one year) }\end{array}$ \\
\hline $\begin{array}{l}\text { Grechko S.M. } \\
{[9, \text { p. 24] }}\end{array}$ & $\begin{array}{l}\text { non-current asset that is intended for economic activity, that is, is planned to be used in eco- } \\
\text { nomic activity }\end{array}$ \\
\hline $\begin{array}{l}\text { Kovaliov D. } \\
{[11, \text { p. } 13]}\end{array}$ & $\begin{array}{l}\text { tangible assets that the enterprise generates in order to use them in the process of production } \\
\text { or supply of goods, provision of services, leasing to other persons or for the implementation of } \\
\text { administrative and socio-cultural functions and the expected useful life of which exceeds a } \\
\text { year. }\end{array}$ \\
\hline $\begin{array}{l}\text { Nemish Yu.B. } \\
{[13, \text { p. 66] }}\end{array}$ & $\begin{array}{l}\text { value of resources held by the entity for use in the production process, supply of goods and } \\
\text { services, leasing to other persons or for implementation of socio-cultural functions, the ex- } \\
\text { pected life of which is at least one year, or determined by the limits of the operational cycle of } \\
\text { more than one year, the cost of which decreases during use }\end{array}$ \\
\hline $\begin{array}{l}\text { Pyrizhok Ye. } \\
{[14, \text { p. 397] }}\end{array}$ & $\begin{array}{l}\text { tangible assets that the company holds in order to their use in the production or supply of } \\
\text { goods, services, to lease to other persons or to carry out administrative and socio-cultural } \\
\text { functions; estimated useful life (operation) is more than one year (or operating cycle, if it } \\
\text { exceeds a year). }\end{array}$ \\
\hline $\begin{array}{l}\text { Suk L.K., Suk P.L. } \\
{[16, \text { p. 262] }}\end{array}$ & $\begin{array}{l}\text { a set of material and property values, operating in natural kind for a long time both in the } \\
\text { sphere of material production and in the non-productive sphere }\end{array}$ \\
\hline $\begin{array}{l}\text { Yalovegha L.V. } \\
{[19, \text { p. 463] }}\end{array}$ & $\begin{array}{l}\text { the amount of capital invested in a set of material and property objects and values used in the } \\
\text { production process to influence the objects of labor and their transformation into the products } \\
\text { suitable for consumption. }\end{array}$ \\
\hline
\end{tabular}

* Compiled by authors on the basis of source analysis 
It is clear from Table 1 that the majority of authors $[6 ; 11 ; 12 ; 13 ; 14]$ took as a basis, the concept included in the normative legal acts of Ukraine, and modified it depending on the purpose of research and management of the enterprise activity.

Some authors, namely Grechko S.M., pay attention to the fact that "... fixed assets are needed for the future economic benefits of enterprises associated with the use of this object in the economic activity." [8, p. 24]. And Yalovegha L.V. determined that "fixed assets are needed for production in order to turn the subject of labour into a finished product". [19, p. 463]

It is also worth noting that an important criterion for the recognition of the object of fixed assets, as scientists consider, is the term of their useful use, which lasts more than one year or the operating cycle, if it is more than one year. In our opinion, this position is correct, since enterprise buys or leases a fixed asset for long-term exploitation during the economic activity.

The necessary element for improving the organization of accounting of fixed assets is their classification. Its focus on all sectors of the national economy - definition of various groups of fixed assets and their association, is of the paramount importance for the organization of accounting, as different groups of fixed assets are allocated and they are united by common functions in the production process. After determining the purpose and classification of the fixed assets, it is possible to optimize their structure - to ensure their effective use, to promote the improvement of the state of production.

The classification of fixed assets is necessary for the correct representation of the revalued value of each item of the fixed assets, accounting and analysis. In the economic literature, different approaches to the classification of fixed assets are used (Table 3).

Table 3

Approaches to the classification of fixed assets in the economic literature (fragment)*

\begin{tabular}{|c|c|c|c|c|c|c|c|}
\hline 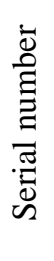 & Classification feature & 窇 & 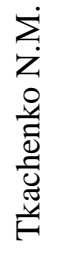 & 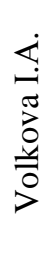 & 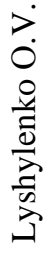 & 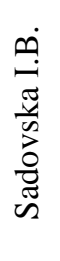 & 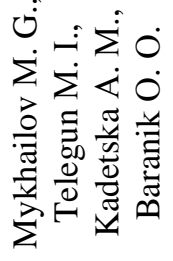 \\
\hline 1. & $\begin{array}{l}\text { Functional purpose: } \\
\text { - production } \\
\text { - non-productive }\end{array}$ & + & - & + & + & + & - \\
\hline 2. & $\begin{array}{l}\text { Belonging to the enterprise: } \\
\text { - own } \\
\text { - leased }\end{array}$ & + & + & + & + & + & + \\
\hline 3. & $\begin{array}{l}\text { Nature of use: } \\
\text { - operating } \\
\text { - spare equipment (temporarily inactive) } \\
\text { - preserved equipment (inactive) } \\
\text { - fixed assets that are leased }\end{array}$ & + & + & + & + & + & + \\
\hline 4. & $\begin{array}{l}\text { Destination purpose of use: } \\
\text { - production purpose } \\
\text { - general purpose designation } \\
\text { - administrative appointment } \\
\text { - fixed assets that are engaged in sales } \\
\text { - fixed assets of cultural and domestic use }\end{array}$ & - & - & - & - & - & + \\
\hline 5. & $\begin{array}{l}\text { For accounting purposes: } \\
\text { 1. fixed assets - land; capital expenditures on land improve- } \\
\text { ment; buildings, constructions and transmitting devices; ma- } \\
\text { chinery and equipment; vehicles; instruments, devices, inven- } \\
\text { tory (furniture) }\end{array}$ & - & + & - & + & - & - \\
\hline & $\begin{array}{l}\text { 2. other non-current tangible assets - fixed assets, other non- } \\
\text { current tangible assets, incomplete capital investments }\end{array}$ & - & - & - & - & - & + \\
\hline 6. & $\begin{array}{l}\text { Purpose of the tax accounting (for the calculation of deprecia- } \\
\text { tion): } \\
\text { - Groups } 1-16\end{array}$ & - & + & - & + & - & + \\
\hline 7. & $\begin{array}{l}\text { Similarity: } \\
\text { - similar } \\
\text { - non-similar }\end{array}$ & - & - & - & - & - & + \\
\hline
\end{tabular}

* Compiled by authors on the basis of source analysis $[6,7,8,15,17,18]$ 
The analysis of publications shows that most authors, namely Suk L.K., Suk P.L. [16, p. 262], Agres O.G. [4, p. 12], Nemish Yu.V. [13, p. 181], Butynets F.F. $[6$, p. 435], use the most common classification of fixed assets by the following features: by grouping by industry, by function, by affiliation, by use. But some authors suggest to classify even by the additional features.

By functional purposes, Tkachenko N.M. considers fixed assets as industrial and productive, productive of other industries, non-productive (non-industrial) [17, p. 260-269].

By state of deterioration, Yu. O. Omelchenko proposed to classify fixed assets on new, usable, obsolete and replaceable ones. He believes that this "... will allow shareholders and other users to constantly have information about the state of fixed assets when making a decision to re-evaluate the property and update them in time" $[18$, p. 9].

The existing classification was also complemented by a team of authors (Mikhailov M.G., Telegun M.I., Kadetska A. M., Baranik O.O.). They highlighted the similarity between them, dividing fixed assets into similar and non-similar ones. According to the authors, such sign is necessary for information provision of assetswap operations [7, p. 190-194].

In determining the essence of fixed assets, scientists allocate different areas of their use. For example, Kovalenko O.V. [10, p. 21] believes that "... the sphere of use of fixed assets is only production processes". But fixed assets are involved both in the production process and in delivery of goods, provision of services, leasing to other persons, implementation of administrative or sociocultural functions. Therefore, such definition of fixed assets is narrow because it does not take into account other areas of their use.

The national accounting standards were developed taking into account the international standards, that is why R (S) A 7 "Fixed assets" [2] has a number of common points in IAS 16 "Fixed Assets" [3].

Definition of the concept of "fixed assets" according to national and international standards can be considered similar (Table 1), but when comparing approaches to the classification of this category there are significant differences. In R(S)A 7 "Fixed assets", classification of fixed assets for the purposes of their accounting is given, and IAS 16 "Fixed assets" distinguishes other classes of fixed assets (Figure 1).

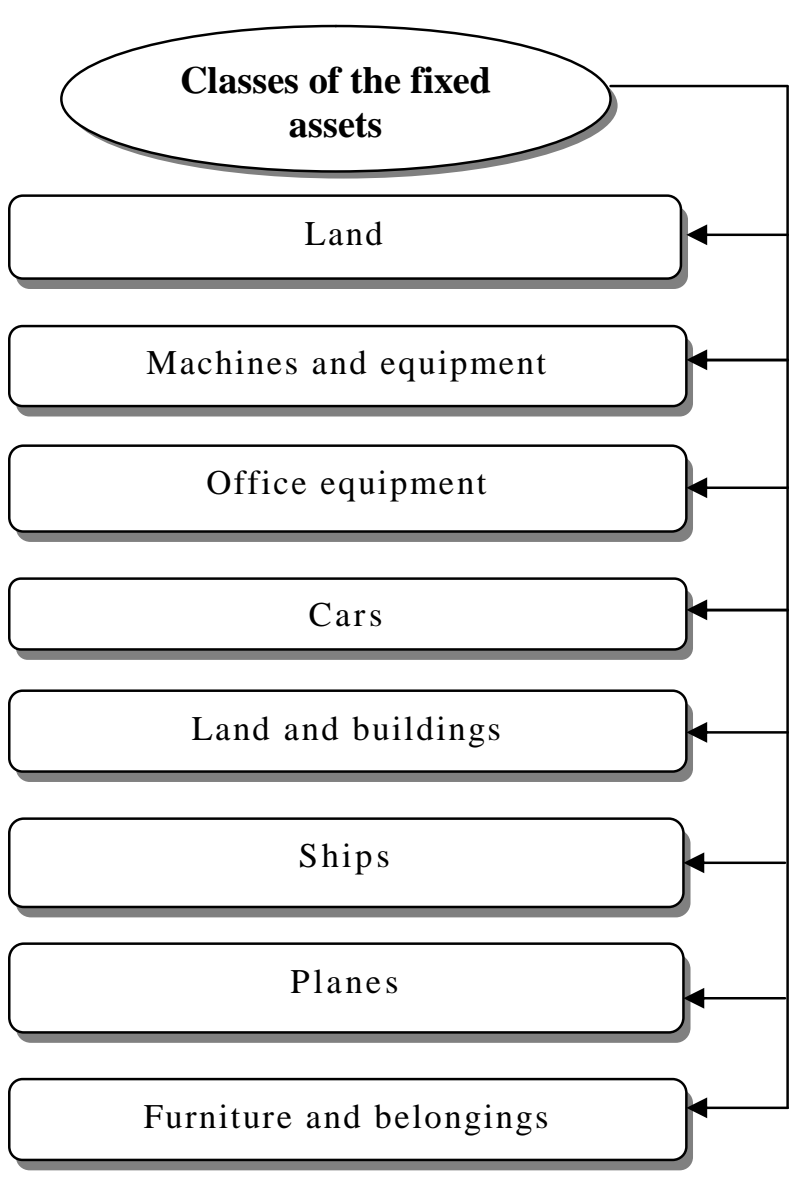

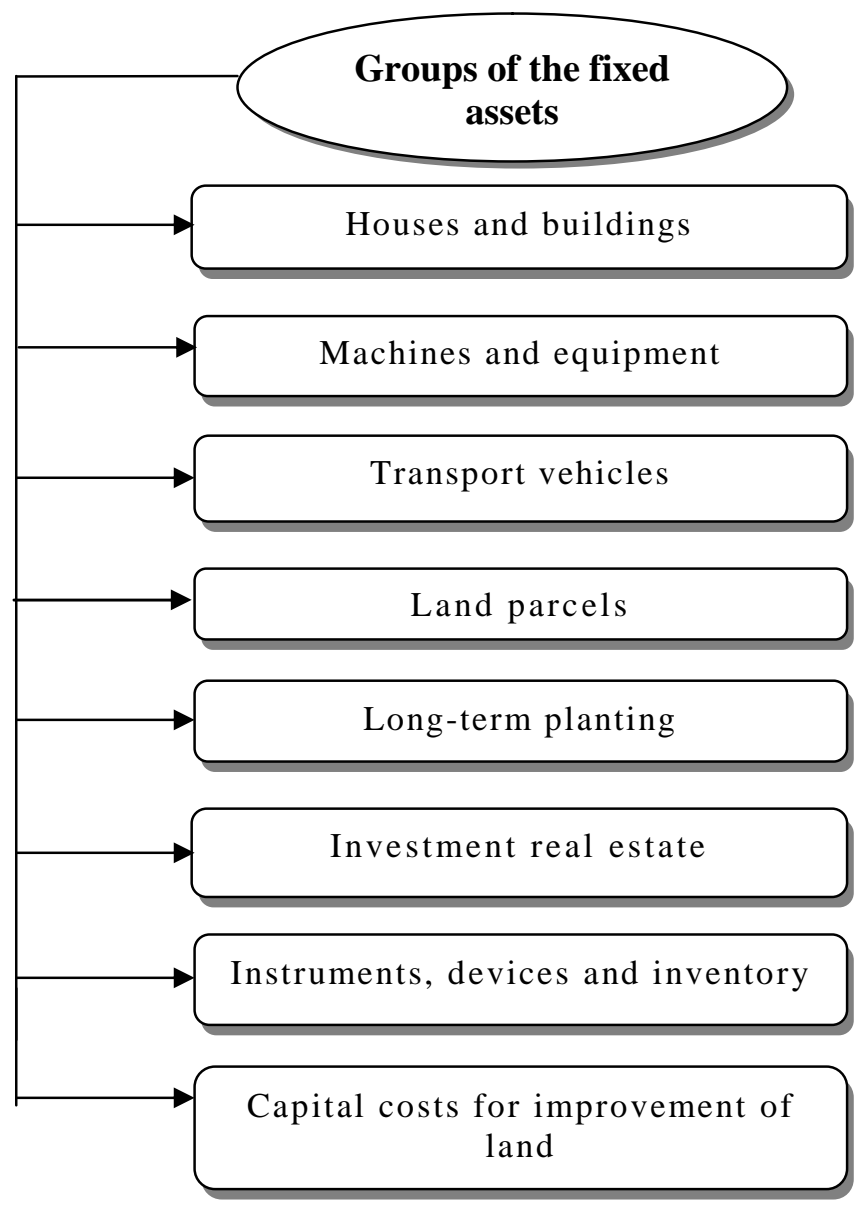

Fig. 1 - Distribution of fixed assets in accordance with the requirements ofR(S)A 7 "Fixed assets" and $\mathrm{I}(\mathrm{S}) \mathrm{A} 16$ "Fixed assets" [20, p. 41] 
In the tax system, 16 groups of fixed assets and other non-current assets are allocated. They coincide with those presented in $\mathrm{R}(\mathrm{S}) \mathrm{A} 7$ "Fixed assets". The difference lies in the fact that, according to each group, the mini- mum permissible useful lives are set. That is, a separate group of fixed assets can not be used less than it is established in Art. 145 of the Tax Code (Fig. 2) [1].

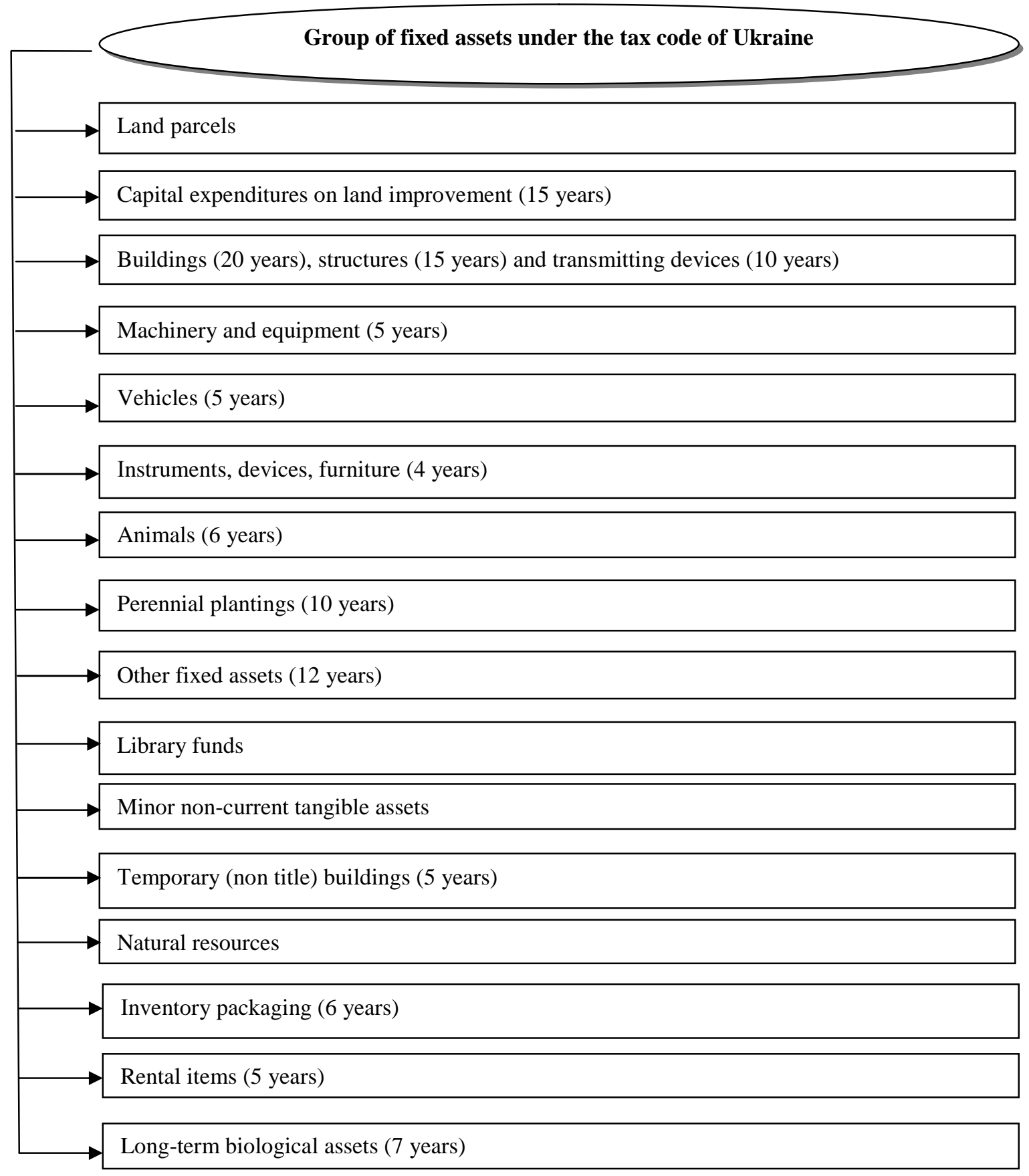

Fig. 2 - Classification groups of fixed assets under the Tax Code of Ukraine*

* compilied by the authors on the basis of sources

In order to display information about fixed assets in the statistical and financial statements, the classification of fixed assets for the purpose of accounting and by types of economic activity is used (Fig. 3).
Thus, the financial statements (Form 5) use the classification of fixed assets for the purpose of accounting, and in statistical statement (Form 11-OZ) - by the types of economic activity. 


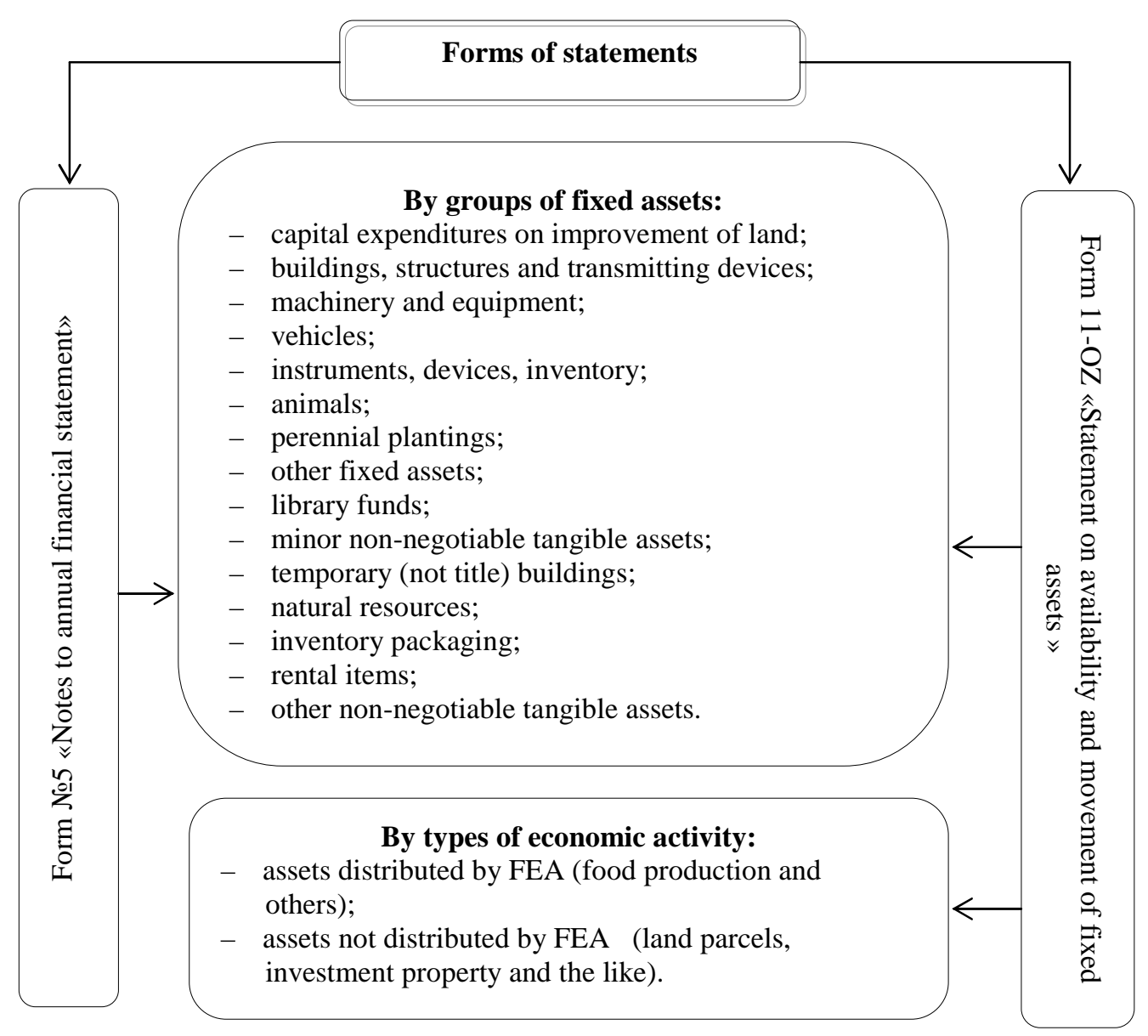

Fig. 3 - Classification of fixed assets in financial and statistic statements*

* compiled by the authors on the basis of the analysis of forms of financial and statistical statements

Conclusions and prospects of the further investigations. Thus in the article the analysis of issues of the economic concept of the category of "fixed assets" and their classification by scientific approach and normative and legal acts has been carried out. The analysis of normative - legal acts allowed us to conclude that under "fixed assets" long-term tangible assets are understood that should be used for more than one year, only Tax Code of Ukraine defines the value criterion by which a non-current asset is included in fixed assets.

The analysis of the essence of the category of fixed assets by the scientific approach has shown that today there is no single approach to the definition of the category of "fixed assets": most authors use the concept, which is given in $\mathrm{R}(\mathrm{S}) \mathrm{A} 7$ "Fixed assets" - "long-term tangible assets that an enterprise uses for their use in the process of producing goods, rendering services, leasing to other persons, expected useful life (exploitation) of which is more than one year. Other scientists modify it depending on the purpose of research and management of the enterprise activity.
The analysis of the classification of fixed assets allowed to make the following conclusions:

- according to the national standards, fixed assets are classified into groups for the purposes of their accounting, and according to the international standards, other classes are allocated;

- the classification of fixed assets for the purposes of accounting and tax accounting for the relevant groups is investigated;

- classification of fixed assets by forms of statistical and financial statements indicates that classification of fixed assets is used in the financial statement for the purpose of accounting and in the statistical reporting - by types of economic activity.

- the analysis of approaches to the classification of fixed assets in the economic literature suggests that domestic researchers mainly examine the classification of fixed assets by the following criteria: by affiliation, by functional purpose, by industry, by use. Use of the additional classification features leads to improved management of fixed assets, qualitative management analysis (including determination of reserves to increase efficiency of the enterprise as a whole) and accounting. 


\section{References}

1. Podatkovyi kodeks Ukrainy 02.12.2010№ 2755-VI: Za stanom na 7 hrudnia 2017 roku. (2018). Retrieved from http://zakon3.rada.gov.ua/laws/show/2755-17

2. Polozhennia (standart) bukhhalterskoho obliku 7 «Osnovni zasoby»: Nakaz Ministerstva finansiv Ukrainy vid 27.04.2000 № 92: Za stanom na 18 chervnia 2015 roku № 1176. (2018). Retrieved from http://zakon0.rada.gov.ua/laws/show/z0288-00

3. Mizhnarodnyi standart bukhhalterskoho obliku 16 «Osnovni zasoby». (2018). Retrieved from www.minfin.gov.ua/document/92427/МСБО_16.pdf

4. Ahres, O. H. (2013). Ekonomichna efektyvnist vykorystannia osnovnykh zasobiv silskohospodarskykh pidpryiemstv. Lviv.

5. Babich, V. (2012). Vytraty na remont ta polipshennia osnovnykh zasobiv: Oblikovyi i podatkovyi aspekty. Bukhhalterskyi Oblik I Audyt, (8), 10-13.

6. Butynets, F. F. (Ed.). (2009). Bukhhalterskyi finansovyi oblik (8-e vyd., dop. i pererob. ed.). Zhytomyr: PP «Ruta»

7. Mykhailov, M. H., Telehun, M. I., Kadetska, A. M., \& Baranik, O. O. (2008). Bukhhalterskyi finansovyi oblik $v$ silskohospodarskykh pidpryiemstvakh. K.: Tsentr uchbovoi literatury.

8. Volkova, I. A. (2008). Finansovyi oblik. K.: Tsentr uchbovoi literatury.

9. Hrechko, S. M. (2011). Osoblyvosti vyznannia osnovnykh zasobiv v tsiliakh bukhhalterskoho obliku ta opodatkuvannia. Problemy Teorii Ta Metodolohii Bukhhalterskoho Obliku, Kontroliu I Analizu,(3(21)), 2nd ser., 23-31.

10. Kovalenko, O. V., \& Hromova, I. V. (2014). Napriamy pidvyshchennia efektyvnosti vykorystannia osnovnykh fondiv pidpryiemstva. Konomichnyi Visnyk Zaporizkoi Derzhavnoi Inzhenernoi Akademii, (7), 20-27.

11. Kovalov, D. (2012, November 28). Dva remonty v odyn den: Yak vykorystaty 10\%-vyi remontnyi limit. Vse Pro Bukhhalterskyi Oblik, pp. 13-14

12. Lyshylenko, O. V. (2009). Finansovyi oblik (3-tie vyd., pererob. i dop. ed.). K.: Tsentr navchalnoi literatury.

13. Nemish, Yu. V. (2012). Poniattia «osnovni zasoby» u suchasnykh naukovykh doslidzhenniakh. Ahrarna Ekonomika, 5(3-4), 181-187.

14. Pyrizhok, Ye. S., \& Kulikova, N. T. (2011). Poniattia «osnovni zasoby» ta kanaly yikh vybuttia na pidpryiemstvi. Mizhnarodnyi Zbirnyk Naukovykh Prats «Problemy Teorii Ta Metodolohii Bukhhalterskoho Obliku, Kontroliu I Analizu», (2(20)), 397-405. literatury.

15. Sadovska, I. B., Bozhydarnik, T. V., \& Nahirska, K. Ye. (2013). Bukhhalterskyi oblik. K.: Tsentr uchbovoi

16. Suk, L. K., \& Suk, P. L. (2012). Finansovyi oblik (2-he vyd., pererob. i dop. ed.). Kyiv.

17. Tkachenko, N. M. (2007). Bukhhalterskyi finansovyi oblik, opodatkuvannia i zvitnist (2-he vyd. dop. i pererob. ed.). K.: Alerta.

18. Omelchenko, O. Yu. (2006). Oblik osnovnykh zasobiv i operatsii po yikh opodatkuvanniu. Kyiv.

19. Yaloveha, L. V. (2013). Oblik vytrat na remont ta polipshennia osnovnykh zasobiv: Bukhhalterskyi i podatkovyi aspekt. Poltavska Derzhavna Ahrarna Akademiia, (10(4)), 460-466.

20. Stupnytska, T., \& Gulavska, K. (2017). Fixed assets of the enterprise: Aspects of theoretical approaches to determination of concept and efficiency of their use. Food Industry Economics, 9(2), 41-41. doi:10.15673/fie.v9i2.641

Received 1 March 2018

Approved 15 March 2018

Available in Internet 7.07.06.2018

Ступницкая Т.M.

кандидат экономических наук, доцент кафедра учета и аудита

E-mail: t.stupnitska@gmail.com

\section{Евтушевская О.А.}

кандидат экономических наук, доцент кафедра учета и аудита

E-mail: olga163alex@gmail.com

\section{Приймак B.O.}

студентка 4 курса фракультета экономики, бизнеса и контроля

Одесская национальная академия пищевых технологий

ул. Канатная, 112, г. Одесса, Украина, 65039

E-mail: priymak_vika@hotmail.com

\section{АНАЛИЗ ПОДХОДОВ К СУЩНОСТИ И КЛАССИФИКАЦИИ ОСНОВНЫХ СРЕДСТВ}

\footnotetext{
Эффрективность использования основных средств зависит от организации своевременного получения надежной и достаточно полной учетно-экономической информации. В связи с чем возрас-
} 
тает роль и значение учета, как одной из важнейших функций управления. Одним из необходимых элементов улучшения организации учета и анализа основных средств является их определение и классификация. В статье проведено исследование сущности категории «основные средства» и подходов к их классификации с целью улучшения управления ими, качественного управленческого анализа и бухгалтерского учета. Проведенное исследование позволило систематизировать подходы к классификации категории «основные средства» по нормативно-правовым актам, которые регулируют их учет и налогообложение всех субъектов хозяйствования. Анализ сущности категории «основные средства» в соответствии с научным подходом показал, что на сегодняшний день отсутствует единый подход к определению категории «основные средства»: большинство авторов использует понятие, которое приведено в П (С) БУ 7 «Основные средства.

Проведенный анализ подходов к классификации основных средств свидетельствует, что по национальным стандартам основные средства классифицируются на группы для целей их учета, а по международным стандартам выделены другие их классы; классификация основных средств по фрормам статистической и финансовой отчетности свидетельствует, что в финансовой отчетности используется классификация основных средств для целей бухгалтерского учета, а в статистической отчетности - по видам экономической деятельности; анализ подходов к классификации основных средств в экономической литературе показал, что отечественные ученые преимущественно рассматривают классификацию основных средств по следующим признакам: по назначению, по функциональному назначению, по отраслям, по использованию.

Использование дополнительных классификационных признаков приводит к улучшению управления основными средствами, проведение качественного управленческого анализа (в том числе определение резервов повышения эффективности деятельности предприятия в целом) и бухгалтерского учета.

Ключевые слова: основные средства, классификация основных средств, группы основных средств, классы основных средств.

Ступницька Т.М.

кандидат економічних наук, доцент кафедра обліку та аудиту

E-mail: t.stupnitska@gmail.com
Євтушевська 0.0.

кандидат економічних наук, доцент

кафедра обліку та аудиту

E-mail: olga163alex@gmail.com

\section{Приймак B.O.}

студентка 4 курсу фракультету економіки, бізнесу і контролю

Одеська національна академія харчових технологій вул. Канатна, 112, м. Одеса, Україна, 65039

E-mail: priymak vika@hotmail.com

\section{АНАЛІЗ ПІДХОДІВ ДО СУТНОСТІ ТА КЛАСИФІКАЦІї ОСНОВНИХ ЗАСОБІВ}

Ефективність використання основних засобів залежить від організації своєчасного одержання надійної і досить повної обліково-економічної інформації. У цьому зв'язку зростає роль та значення обліку як однієї з найважливіших функцій управління. Одним з необхідних елементів покращення організації обліку та аналізу основних засобів є їх визначення та класифікація. У статті проведено дослідження сутності категорії «основні засоби» та підходів до їх класифікації з метою покращення управління ними, проведення якісного управлінського аналізу та бухгалтерського обліку. Проведене дослідження дозволило систематизувати підходи до класифікації категорії «основні засоби» за нормативно-правовими актами, які регулюють їх облік та оподаткування всіх суб'єктів господарювання. Аналіз сутності категорії основних засобів за науковим підходом показав, що на сьогодні відсутній єдиний підхід щодо визначення категорії «основні засоби»: більшість авторів використовує поняття, яке наведено в П(С)БО 7 «Основні засоби.

Проведений аналіз підходів до класифікації основних засобів показав, що за національними стандартами основні засоби класифікуються на групи для цілей їх обліку, а за міжнародними стандартами виділені інші їх класи; класифікація основних засобів за формами статистичної та фрінансової звітності свідчить, що у фінансовій звітності використовується класифікація основних засобів з метою бухгалтерського обліку, а у статистичній звітності - за видами економічної діяльності; аналіз підходів до класифікації основних засобів в економічній літературі показав, що вітчизняні вчені переважно розглядають класифікацією основних засобів за такими ознаками: за належністю, за функціональним призначенням, за галузями, за використанням. 
Використання додаткових класифікаційних ознак призводить до покращення управління основними засобами, проведення якісного управлінського аналізу (в тому числі визначення резервів підвищення ефективності діяльності підприємства в цілому) та бухгалтерського обліку.

Ключові слова: основні засоби, класифікація основних засобів, групи основних засобів, класи основних засобів.

\section{Література}

1. Податковий кодекс України 02.12.2010№ 2755-VI: за станом на 7 грудня 2017 року[Електронний ресурс]. - Режим доступу: http://zakon3.rada.gov.ua/laws/show/2755-17

2. Положення (стандарт) бухгалтерського обліку 7 «Основні засоби»: наказ Міністерства фінансів України від 27.04.2000 № 92: за станом на 18 червня 2015 року № 1176 [Електрон. ресурс]. - Режим доступу: http://zakon0.rada.gov.ua/laws/show/z0288-00

3. Міжнародний стандарт бухгалтерського обліку 16 «Основні засоби» [Електронний ресурс] // Міністерство Фінансів України. - Режим доступу : www.minfin.gov.ua/document/92427/MСБО_16.pdf

4. Агрес О.Г. Економічна ефективність використання основних засобів сільськогосподарських підприємств : автореф. дис. на здобуття наук. ступеня канд. ек. наук: спец. 08.00 .04 «Економіка та управління підприємствами (за видами економічної діяльності)» / Агрес О.Г. - Львів, 2013. - 20 с.

5. Бабіч В. Витрати на ремонт та поліпшення основних засобів: обліковий і податковий аспекти / В. Бабіч // Бухгалтерський облік і аудит. - 2012. - № 8. - С. 10-13.

6. Бухгалтерський фінансовий облік: [підруч.] / за заг. ред.Ф.Ф. Бутинця. - [8-е вид., доп. і перероб. ]. Житомир: ПП «Рута», 2009. - 912 с.

7. Бухгалтерський фінансовий облік в сільськогосподарських підприємствах : [навч. посібник] / Михайлов М. Г., Телегунь М. І., Кадецька А. М., Баранік О. О. - К. : Центр учбової літератури, 2008. - 472 с.

8. Волкова I. А. Фінансовий облік: [навч. посібник] / І. А. Волкова. - К.: Центр учбової літератури, 2008. - $228 \mathrm{c}$.

9. Гречко С.М. Особливості визнання основних засобів в цілях бухгалтерського обліку та оподаткування / С.М. Гречко // Проблеми теорії та методології бухгалтерського обліку, контролю і аналізу. - 2011. - № 3(21). - Ч. 2. - С. 23-31.

10. Коваленко О.В. Напрями підвищення ефективності використання основних фондів підприємства / О.В. Коваленко, І.В. Громова // Економічний вісник Запорізької державної інженерної академії. - 2014. - Вип. 7. - C. 20-27.

11. Ковальов Д. Два ремонти в один день: як використати 10\%-вий ре-монтний ліміт / Д. Ковальов // Все про бухгалтерський облік. - 2012. -№ 108, 28 листопада. - С. 13-14.

12. Лишиленко О. В. Фінансовий облік: [підручник] / О. В. Лишиленко. - [3-тє вид., перероб. і доп.] К.: Центр навчальної літератури, 2009. - 670 с.

13. Неміш Ю.В. Поняття «основні засоби» у сучасних наукових дослідженнях / Ю.В. Неміш // Аграрна економіка. - 2012. - Т. 5, № 3-4. - С. 181-187

14. Пиріжок Є.С. Поняття «основні засоби» та канали їх вибуття на підприємстві / Є.С. Пиріжок, Н.Т. Кулікова // Міжнародний збірник наукових праць «Проблеми теорій та методології бухгалтерського обліку, контролю і аналізу». - 2011. - Випуск 2 (20). - С. 397-405.

15. Садовська І. Б. Бухгалтерський облік: [навч. посібник] / І. Б. Садовська, Т. В. Божидарнік, К. С. Нагірська. - К.: Центр учбової літератури, 2013. - 688 с 2012. $-647 \mathrm{c}$.

16. Сук Л.К. Фінансовий облік : [навч. посіб.] / Л.К. Сук, П.Л. Сук. - [2-ге вид., перероб. і доп.] - К.,

17.Ткаченко Н. М. Бухгалтерський фінансовий облік, оподаткування і звітність: [підручник] / Н. М. Ткаченко. - [2-ге вид. доп. і перероб.]. - К. : Алерта, 2007. - 954 с.

18.Омельченко О. Ю. Облік основних засобів і операцій по їх оподаткуванню : автореф. дис. на здобуття наук. ступеня канд. ек. наук : спец. 08.06.04 «Бухгалтерський облік, аналіз і аудит»/ Омельченко О. Ю. - К., 2006. -23 c.

19. Яловега Л.В. Облік витрат на ремонт та поліпшення основних засобів: бухгалтерський і податковий аспект / Л.В. Яловега // Полтавська державна аграрна академія. - 2013. - № 10(4). С. 460-466

20. Stupnytska T. Fixed assets of the enterprise: aspects of theoretical approaches to determination of concept and efficiency of their use / T. Stupnytska, K. Gulavska // Food industry economics. - 2017. - Vol.9, Issure 2. - P.41; DOI: 10.15673/fie.v9i2.641 